\title{
Tanaman Penutup Tanah Untuk Mencegah Erosi
}

\author{
Oleh: Budiwati \\ Staf Pengajar FMIPA UNY \\ Email:bwt_wati@yahoo.co.id
}

\section{Pendahuluan}

Menurut prediksi para ahli, nasib bumi beberapa tahun mendatang makin memprihatinkan. Pemanasan global mengakibatkan naiknya permukaan air laut dan perubahan iklim. Lapisan ozon makin menipis menyebabkan sinar UV menembus dan meningkatkan suhu bumi menjadi makin tinggi. Belum lagi resiko banjir besar. Saat ini kita juga bisa merasakan bahwa udara yang kita hirup tidak sesegar dulu lagi. Penyumbang terbesar terjadinya kondisi ini adalah perilaku manusia. Demi memenuhi kebutuhan hidupnya, manusia seringkali melakukan aktivitas yang secara langsung ataupun tidak langsung dapat merusak alam, misalnya penebangan hutan secara liar, penggunaan pestisida dan pupuk kimia sintetis dalam bidang pertanian, penggunaan barang berbahan dasar CFC (chlorofluorocarbon), membuang sampah di saluran air, dan sebagainya. Akibat perilaku tersebut terjadilah kerusakan alam yang dapat menyebabkan bencana alam.

Banjir dan tanah longsor merupakan bencana alam yang biasa terjadi di Indonesia. Pada saat musim penghujan tiba, ada saja daerah yang terkena banjir dan tanah longsor. Beberapa daerah seperti Jakarta dan Bandung sudah terbiasa mengalami banjir saat musim penghujan. Namun akhir-akhir ini beberapa daerah yang biasanya terbebas dari banjir tak luput juga dari genangan banjir. Akibat dari bencana alam yang terjadi banyak warga kehilangan harta benda bahkan nyawa. Aktivitas warga setempat menjadi terganggu bahkan seringkali menjadi lumpuh total. Siswa terpaksa diliburkan karena bangunan sekolah terendam air ataupun rusak. Lahan pertanian, kolam pemeliharaan ikan terendam banjir sehingga tidak bisa diharapkan lagi hasilnya. Tak terbayangkan kerugian yang diakibatkan oleh bencana banjir. Dalam artikel berikut akan disampaikan penyebab banjir, erosi dan bagaimana tanaman penutup tanah dapat mencegah erosi. 


\section{Penyebab Banjir}

Secara umum bencana alam banjir diakibatkan oleh faktor alam dan perilaku manusia.Berikut ini beberapa hal yang berpotensi menyebabkan terjadinya bencana banjir.

1. Curah hujan yang tinggi.

Curah hujan yang tinggi merupakan faktor alam yang sulit dicegah. Pada musim penghujan, curah hujan yang tinggi akan menyebabkan banjir di sungai. Bila tinggi air melebihi tebing sungai, air akan meluap dan menyebabkan banjir di kawasan sekitar sungai.

2. Lahan Gundul

Lahan gundul merupakan salah satu faktor penyebab utama bencana banjir di Indonesia. Lahan gundul merupakan akibat dari penebangan hutan secara liar yang dilakukan oleh orang yang tidak bertanggung jawab, yang hanya mementingkan diri sendiri. Kini banyak hutan yang sudah tidak mampu lagi menampung air dalam jumlah besar. Keadaan ini sangat berpotensi menyebabkan banjir.

3. Alih Fungsi Lahan

Alih fungsi lahan juga merupakan salah satu penyebab utama terjadinya banjir. Pada umunya terjadinya alih fungsi lahan akibat meningkatnya jumlah penduduk. Kebutuhan tempat tinggal dan meningkatnya aktivitas manusia tentu saja memerlukan lahan. Akibatnya banyak lahan yang semula merupakan daerah resapan yang mampu menampung air dalam jumlah besar berubah menjadi kawasan yang penuh bangunan.

4. Erosi Tanah

Hal lain yang bisa menyebabkan terjadinya bencana banjir adalah erosi tanah. Hujan yang terjadi terus menerus menyebabkan tanah terbawa oleh air dalam jumlah yang sangat besar sehingga hanya menyisakan bebatuan saja. Bebatuan ini tidak bisa menyimpan air, dan jika terjadi hujan besar maka air akan terus mengalir menjadi banjir.

5. Pendangkalan Sungai.

Pendangkalan sungai atau yang biasa disebut sedimentasi merupakan salah satu faktor penyebab banjir di Indonesia ini.Sedimentasi ini bisa terjadi karena erosi. Air yang tidak meresap ke dalam tanah akan mengalir ke tempat yang lebih rendah. 
Terkadang air yang mengalir ini akan membawa serta tanah yang tidak tertahan. Tanah yang terbawa air tersebut bisa menumpuk di sungai dan menyebabkan pendangkalan. Pendangkalan ini menyebabkan berkurangnya daya tampung sungai. Apabila ada aliran air yang cukup besar akan menyebabkan banjir. Sebagai contoh kasus, tahun 2008 terjadi banjir besar di sepanjang aliran Bengawan Solo akibat sedimentasi. Diperkirakan sedimen yang masuk ke waduk Gajah Mungkur mencapai 100 juta $^{3}$ (Rahman, Harisuseno dan Sisinggih, 2012).

6. Sampah

Salah satu perilaku manusia yang bisa menyebabkan banjir adalah kebiasaan membuang sampah di saluran air. Sampah ini akan menyumbat saluran-saluran air sehingga air meluap dan akhirnya menyebabkan banjir. Sampah juga menyebabkan sedimentasi di sungai yang membuat sungai menjadi dangkal.

7. Keadaan Tanah dan Tanaman.

Daerah yang tanahnya subur dan ditumbuhi banyak tanaman tentu memiliki daya serap air yang baik sehingga mengurangi kemungkinan terjadinya banjir. Sedangkan daerah-daerah yang tertutup semen, aspal dan bahan-bahan lain yang sulit untuk menyerap air berpotensi terjadi banjir.

8. Rusaknya Saluran Air

Rusaknya saluran air seperti selokan, parit, sungai dan lain-lainnya menyebabkan air meluap dimusim penghujan dan ini bisa menyebabkan banjir.

\section{Erosi}

Di antara beberapa penyebab banjir di atas, erosi merupakan salah satu faktor yang sangat besar potensinya sebagai penyebab banjir. Selain menyebabkan banjir, kerusakan tanah akibat erosi dapat mengakibatkan menurunnya kesuburan dan produktivitas tanah, pendangkalan sungai dan danau serta makin meluasnya lahan kritis. Menurut Wiryono (2013) erosi merupakan terlepasnya partikel tanah dari tempat aslinya, lalu terbawa ke tempat lain. Erosi dapat disebabkan oleh air atau angin. Terjadinya erosi ditentukan oleh faktor iklim, topografi, karakteristik tanah, kerentanan tanah terhadap erosi, vegetasi penutup tanah, dan tata guna lahan.

Erosi dapat terjadi secara alami, prosesnya berjalan sangat lambat. Meskipun lambat, dalam jangka waktu berjuta-juta tahun, mampu mengikis gunung-gunung tinggi menjadi lebih pendek. Erosi buatan manusia prosesnya jauh lebih cepat. Contoh erosi buatan manusia 
adalah kasus penebangan hutan di Pegunungan Dieng. Para petani mengubah hutan menjadi kebun kentang. Karena lahannya miring, maka dalam beberapa tahun lapisan tanah atas terkikis. Kesuburan tanah berkurang drastis karena lahannya menjadi daerah berbatu-batu. Oleh karena itu petani memberikan banyak pupuk yang tentu saja merugikan lingkungan. Erosi tersebut ternyata juga menyebabkan sedimentasi pada danau-danau di kawasan tersebut (Wiryono, 2013).

Untuk menyelamatkan bumi ini dari gerusan erosi perlu dilakukan konservasi dengan tujuan melindungi tanah dari curahan langsung air hujan dan menahan hanyutan aliran air. Usaha konservasi bisa dilakukan dengan metode mekanik, misalnya dengan pembuatan teras dan parit. Metode konservasi tanah yang lain yaitu metode vegetatif. Metode vegetative dilakukan dengan memanfaatkan bagian-bagian dari tanaman (daun, batang, ranting) untuk menahan air hujan agar tidak langsung mengenai tanah. Selain itu akar tanaman berfungsi meningkatkan daya resap tanah dan menjaga aliran permukaan agar tidak merusak tanah.

\section{Tanaman Penutup Tanah}

Salah satu cara menerapkan metode vegetatif yaitu dengan penanaman tanaman penutup tanah.Tanaman penutup tanah yaitu tanaman yang khusus ditanam untuk melindungi tanah dari ancaman kerusakan oleh erosi dan untuk memperbaiki kondisi tanah. Tanaman penutup tanah mempunyai peranan: (1) menahan atau mengurangi daya perusak butir-butir hujan yang jatuh dan aliran air di atas permukaan tanah, (2) menambah bahan organik tanah melalui batang, ranting dan daun mati yang jatuh, dan (3) menyerap air dan melakukan transpirasi.

Tanaman yang digunakan sebagai penutup tanah sebaiknya mudah diperbanyak, mempunyai sistem perakaran yang tidak menimbulkan kompetisi berat bagi tanaman pokok, tetapi mempunyai sifat sebagai pengikat tanah yang baik. Selain itu tidak mensyaratkan tingkat kesuburan tanah yang tinggi, tumbuh cepat, banyak menghasilkan daun dan tidak berubah menjadi gulma.

Tanaman penutup tanah sebaiknya bertingkat, terdiri dari tanaman penutup tanah rendah, sedang (perdu) dan tinggi (pelindung). Tanaman penutup tanah rendah misalnya Ageratum conyzoides L (babandotan), Andropogon zizanoides (akar wangi), Panicum maximum (rumput benggala), Panicum ditachyum (balaban, paitan), Paspalum dilatum (rumput Australia), Pennisetum purpureum (rumput gajah), Centrosema pubescens Benth. 
Tanamaan penutup tanah sedang (perdu), misalnyaLantana camara L (tahi ayam), Crotalaria anagyroides HBK, Tephrosia candida DC, Tepherosia vogelii,Desmodium gyroides DC (kakatua, jalakan). Acacia villosa Wild, Sesbania grandiflora PERS (turi), Calliandra calothyrsus Meissn (kaliandra merah), Gliricidia maculata (gamal), Clorataria juncea (orok-orok),Cajanus cajan Nillst (kacang gude), Leucaena glauca (L) Benth (pete cina, lamtoro, kemlandingan).

Tanaman penutup tanah tinggi (pelindung)misalnyaAlbizia falcata (sengon laut, jeunjing), Pithecellobium saman benth (pohon hujan), Erythrina sp.(dadap), Gliricidia sepium,Leucaena glauca atau Leucaena leucocephala,Albizia procera Benth, Acacia melanoxylon, Acacia mangium, Eucalyptus saligna,Cinchona succirubra,Gigantolochloa apus (bambu apus), Dendrocalamus asper (bambu betung) Bambusa vulgaris (bambu wulung).
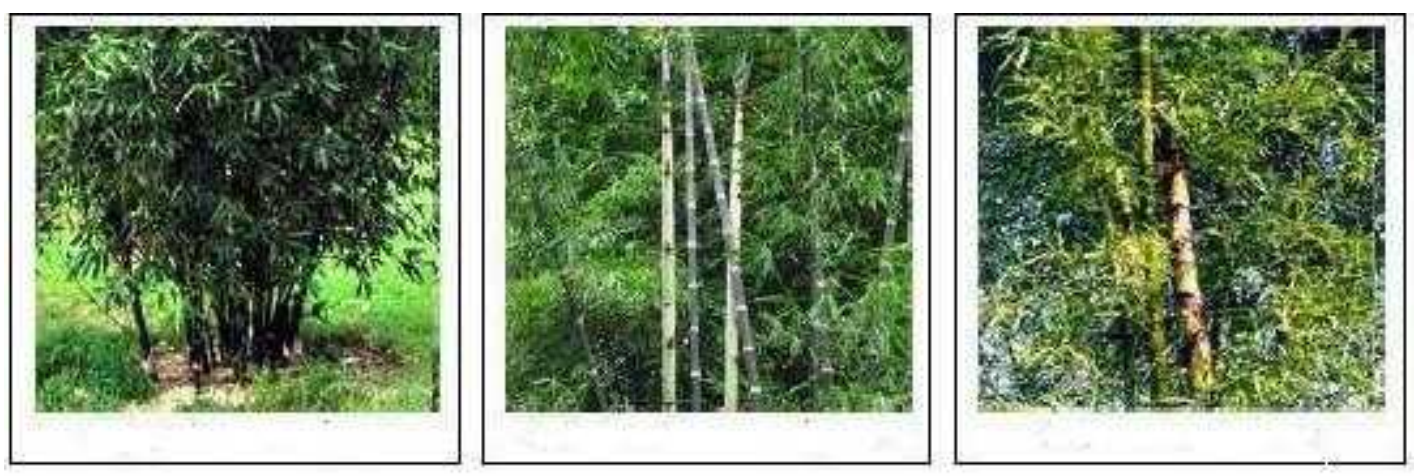

Gambar 1. Tiga jenis bambu yang sering dimanfatkan sebagai tanaman penutup tanah. Dari kiri ke kanan: Gigantochloa apus, Dendrocalamus asper, dan Bambusa bambos (sumber: http://bebasbanjir2025.wordpress.com/teknologi-pengendalianbanjir/tanaman-penutup-tanah, diakses tanggal 27 Maret 2014)

Pemilihan tanaman penutup tanah selain memenuhi persyaratan, sebaiknya dipertimbangkan juga manfaat tanaman secara ekonomi. Dengan harapan, selain bermanfaat dalam pelestarian lingkungan, penduduk setempat bisa memperoleh penghasilan tambahan dari tanaman tersebut. Salah satu contoh tanaman yang memenuhi kriteria tersebut adalah bambu. Bambu memiliki struktur akar serabut yang kuat sehingga mampu menahan laju erosi. Pertumbuhan rumpun bambu sangat cepat dan toleransi terhadap lingkungan sangat tinggi, serta memiliki kemampuan memperbaiki sumber tangkapan air yang efektif sehingga sesuai untuk reboisasi wilayah hutan terbuka atau gundul akibat penebangan. Bambu juga sesuai sebagai tanaman pelindung tebing sungai atau jurang. 
Beberapa keunggulan lain bambu yang adalah: (1) mudah ditanam dan tidak memerlukan pemeliharaan khusus, (2) untuk melakukan budidaya bambu tidak diperlukan investasi yang besar, setelah tanaman sudah mantap, hasilnya dapat diperoleh secara terus menerus tanpa menanam lagi, (3) memiliki kelebihan yaitu serat panjang dan rapat, lentur tidak mudah patah, dinding keras, (4) kecepatan pertumbuhan bambu dalam menyelesaikan masa pertumbuhan vegetatifnya merupakan tercepat dan tidak ada tanaman lain yang sanggup menyamainya, (5) memiliki ketahanan yang luar biasa, sebagai contoh: rumpun bambu yang telah dibakar masih dapat tumbuh lagi, bahkan pada saat bencana sunami di Aceh Desember 2004, bambu masih bisa tegak berdiri sementara pohon yang lain tumbang, (6) mempunyai nilai ekonomis tinggi karena hampir semua bagian tubuhnya dapat dimanfaatkan, tunasnya yang kita kenal sebagai rebung dari beberapa jenis bambu dapat dijadikan sebagai bahan makanan yang bergizi tinggi, daunnya untuk membungkus makanan, batangnya untuk bangunan, kerajinan dan sebagai bahan pembuatan alat musik tradisional, serat batangnya bisa juga digunakan untuk membuat kertas.

\section{Penutup}

Bumi sebagai tempat tinggal kita sudah selayaknya kita rawat dengan baik dan jaga jangan sampai rusak. Salah satu yang menyebabkan kerusakan bumi adalah erosi. Cara yang ramah lingkungan dapat kita lakukan untuk menyelamatkan bumi dari gerusan erosi yaitu dengan menanam tanaman penutup tanah (metode vegetatif). Pengelolaan tanah secara vegetatif dapat menjamin keberlangsungan keberadaan tanah dan air karena memiliki sifat memelihara kestabilan struktur tanah melalui sistem perakaran tanaman, penutupan lahan oleh seresah dan tajuk mengurangi evaporasi. Disamping itu tanaman dapat meningkatkan aktivitas mikroorganisme tanah yang mengakibatkan peningkatan porositas tanah, sehingga memperbesar jumlah infiltrasi dan mencegah terjadinya erosi. Apabila tanaman yang digunakan sebagai tanaman penutup adalah tanaman yang memiliki nilai ekonomis, tentu saja akan bermanfaat untuk menambah penghasilan warga setempat.

\section{Daftar Pustaka}

Anonim. 2014. Berbagai Macam Penyebab Bencana Alam Banjir di Indonesia. http://www.invonesia.com/penyebab-bencana-alam-banjir.html. Diakses 30 Maret 2014 
Anonim. Tanaman Penutup Tanah. Diakses dari http://bebasbanjir2025.wordpress.com/teknologi-pengendalian-banjir/tanamanpenutup-tanah tanggal 27 Maret 2014

Balai Penelitian Tanah. 2005. Konservasi Tanah pada Lahan Usaha Tani Berbasis Tanaman Perkebunan.http://balittanah.litbang.deptan.go.id/dokumentasi/leaflet/konservasi .pdf. diakses 1 Aril 2014

Bambang Ruwanto. 2008. Mengenal Bencana Alam -Banjir . Yogyakarta: Penerbit Kanisius

Firmansyah. 2013. Jenis dan Manfaat Bambu. Diakses dari http://firmansyahbetawi.wordpress.com/2013/033/11/jenis-dan-manfaat-bambu/ tanggal 30 Maret 2014

Rahman,M.M, Harisuseno,D. dan D. Sisinggih. 2012. Studi Penanganan Konservasi lahan di Sub DAS Keduang DAS Bengawan Solo Kabupaten Wonogiri. Jurnal Teknik Pengairan Vol 3, Nomor 2, Desember 2012, hlm 250-257. Diakses dari http://jurnalpengairan.ub.ac.id/pada tanggal29 Maret 2014

Rahmat Rukmana. 1995. Teknik Pengelolaan Lahan Berbukit dan Kritis. Yogyakarta: Penerbit Kanisius.

Suhardi.Efektifitas Vegetatif dalam Konservasi Tanah Dan Air pada Suatu Das. Diakses dari http://www.dishut.jabarprov.go.idpada tanggal 29 Maret 2014

Tjitrosoepomo, G. 1989. Taksonomi Tumbuhan(Spermatophyta). Yogyakarta: Gadjah Mada University Press.

Wiryono. 2013. Pengantar Ilmu Lingkungan. Bengkulu: Badan Penerbitan Fakultas Pertanian Universitas Bengkulu. 